\title{
NEEDS ANALYSIS OF TASK-BASED MODEL OF ARABIC NURSING SYLLABUS
}

\author{
Ahmad Murodi, Emzir, Aceng Rahmat \\ Universitas Negeri Jakarta, Indonesia \\ Jl. R. Mangun Muka Raya, Rawamangun, Kota Jakarta Timur, 13220, Indonesia \\ CorrespondingE-mail:abmad.murodi@unj.ac.id
}

\begin{abstract}
The purpose of this study is to find the needs of task-based model syllabus for Arabic language learning in Nursing Academy at As-Syafi'yah Islamic University in Jakarta. Currently, most of the specific language syllabus does not fulfil the student needs and its content that is the language used is very general and did not really based on the needs of students. The study analyses the student needs using descriptive analysis method. While the data will be collected from document, questionnaire, and interview. Then, the data analysed will be validated by expert of qualitative technique. There are three steps of process will go through, namely data reduction, data display, and taking conclusion. The result of study shows that task-based model of Arabic nursing sylabus which is refered to Indonesia's national qualification framework is proper and decent to be used as the guidance of Arabic teaching and learning process at Nursing Academy of As-Syafi'yah Islamic University Jakarta.
\end{abstract}

Keywords: $\quad$ Arabic, nursing, syllabus, task-based model

\section{Introduction}

As-Syafi'yah Islamic University Jakarta in Nursing Academy strives to produce graduates who are not only reliable in the field of health, but also have a high level of mastery of Arabic language. Thus, they are able to compete in the international sphere. In Arabic teaching does not only explain modern linguistics that describes language variations because they are dynamic and real. The focus of language teaching is on mastering grammar and translation in acquiring four language skills, namely listening, speaking, reading and writing. Then, the ideal skills in learning Arabic nursing include four language skills. From the real conditions faced that the ideal expectations of graduates to be achieved can not be fulfilled, especially for the achievement of mastery of Arabic. The reality faced by Arabic language lectures for nursing at As-Syafi'iyah University still faces problems.

The results of preliminary observations found a common problem in the process of achieving an ideal Arabic language learning is the development of theories 
and methods of teaching Arabic in Indonesia is very slow compared to teaching other foreign languages such as English. This is due to several factors. First, verbal teaching in Arabic. Second, the teaching of Arabic is very closely related to the deepening of the Islamic religion. Third, the teaching of Arabic aims to make students able to understand and translate traditional Arabic texts. In addition, it must be acknowledged, that Arabic lecturers at Akper UIA do master Arabic, but there are those who do not understand the learning methodology. From the socio-cultural point of view, the map of Arabic teaching at Akper UIA is in a social environment that is less conducive. And in terms of linguistics, that the Arabic language system is very different from the Indonesian language system.

Indicators of nursing Arabic learning problem came from students, lecturers and curriculum. Therefore, learning design of Arabic nursing requires a curriculum system that is able to meet the development needs of Arabic and global education. It is in the syllabus design of Arabic teaching materials used at the Nursing Academy. The syllabus has to be appropriate with the students needs and goals of learning.

The result of syllabus document analysis show that content of syllabus is still not appropriate with the current curriculum goals. It is not in accordance with Indonesia national curriculum framework (KKNI). It has been adapted to scientific development, global needs, and industry. Thus, it can be concluded that the syllabus of Arabic learning needs to be continually developed, but it must still be based on an existing syllabus in order to remain sustainable.

Previous research showed that the syllabus is designed based on multi features namely basic lingusitic, style, and lexical for 3 surahs. ${ }^{1}$ This study aims to design a syllabus for new Muslims. While, Woods, Luke, \& Weir studied that the terms curriculum and syllabus have technical debates in education. Both are used to create high quality education and have an effective balance. ${ }^{2}$ In Rahimpour's research found that there are 6 syllabus that became terminally in the last decade for teaching foreign languages, namely (a) structural syllabus (b) notional/functional syllabus (c) situational syllabus (d) skill-based syllabus (e) content-based syllabus (f) task-based syllabus. ${ }^{3}$ The design of the syllabus must be in accordance with the needs and views of the designer and the needs of students. So as, it is in accordance with the applicable education system. ${ }^{4}$ The same thing has been done by Cowling, ${ }^{5}$ schools and lectures must

${ }^{1}$ A. A. Saleh \& T. Elyas, "Advances in language and literary studies : AL \&amp; LS", Advances in Language and Literary Studies, Vol. 6, 2015.

2 A. Woods, A. Luke, \& K. Weir, "Curriculum and Syllabus Design", International Encyclopedia of Education, 2010, 362-367.

${ }^{3}$ M. Rahimpour, "Current trends on syllabus design in foreign language instruction", Procedia Social and Behavioral Sciences, Vol. 2, No. 2, 2010a, 1660-1664.

${ }^{4}$ Z. Bazyar, M. Dastpak, \& A. Taghinezhad, "Syllabus Design and Needs Analysis of Students in Educational System”, Australian International Academic Centre, Vol. 6, No. 4, 2015, 2203-4714.

${ }^{5}$ J. D. Cowling, "Needs analysis: Planning a syllabus for a series of intensive workplace courses at a leading Japanese company", English for Specific Purposes, Vol. 26, No. 4, 2007, 426-442. 
conduct a needs analysis on a regular basis to always update the curriculum. ${ }^{6}$ The syllabus design is not only oriented to the needs of students, but it must also be centered on human values. As in research Jones has redesigned learning in the first year for the syllabus of writing using a humanitarian-based approach. ${ }^{7}$

From some of these studies, it is known that previous studies are oriented to syllabus design in accordance with the objectives and learning needs. However, this research is aimed at designing a syllabus that is not only oriented towards the needs of students, but it is adapted to the concept of the subject of learning Arabic for Nursing majors in accordance with current global challenges, and also the problems faced by students. Learning Arabic in the nursing study program is part of special learning, that leads not only to the linguistic context, but also the content of the health field. Thus, the syllabus designed in this study is suitable for the needs of learning Arabic for the specific purpose of the Nursing study program. This study was undertaken to investigate the needs analysis of task-based model of Arabic nursing syllabus.

\section{Method}

The method of study was descriptive qualitative method. Qualitative research is refered to the comprehending of social phenomena using human perspective. ${ }^{8}$ This study described lecture and student needs for Arabic nursing syllabus. The participant of study are lecture and students that is in Arabic nursing program study. They answer some questions in questionnaire about Arabic nursing syllabus. The location of research is As-Syafi'yah Islamic University Jakarta in Nursing Academy. The research has some techniques to collect the data, namely;

Table 1. Techniques to collect the data

\begin{tabular}{lll}
\hline \multicolumn{1}{c}{ Techniques } & \multicolumn{1}{c}{ Aims } & Participant \\
\hline Documentation & $\begin{array}{l}\text { The aim is to analyze the syllabus } \\
\text { which has used in Nursing Academy at }\end{array}$ & Document \\
& As-Syafi'yah Islamic University Jakarta & \\
\hline Interviews & It is for lecture and students. Data & Lecture \\
& used to emphasize analysis of syllabus & Students \\
& needs. & \\
\hline Questionnaire & It has some question that ask to & Lecture \\
& $\begin{array}{l}\text { lecture and students about syllabus } \\
\text { needs about Arabic nursing material }\end{array}$ & \\
\hline
\end{tabular}

Process of data analysis used judgment expert to determine syllabus eligibility. The data show in descriptive qualitative analysis.

${ }^{6}$ S. Al-Hamlan \& A. A. Baniabdelrahman, "A Needs Analysis Approach to EFL Syllabus Development for Second Grade Students in Secondary Education in Saudi Arabia: A Descriptive Analytical Approach to Students' Needs", American International Journal of Contemporary Research, Vol. 5, No. 1, 2015.

${ }^{7}$ N. N. Jones, "Human Centered Syllabus Design: Positioning Our Students As Expert EndUsers", Computers and Composition, 49, 2018, 25-35.

8 Donald Ary, Lucy Cheser Jacobs, Christine K. Sorensen Irvine, \& David A. Walker, Introducation to Research in Education, (Boston: Cengage, 2009). 


\section{Result}

Needs analysis refers to 3 concepts of the theory of Brindley, ${ }^{9}$ Hutchinson and Waters, ${ }^{10}$ and Nation and Macalister. ${ }^{11}$ Their concept has combined to be two main parts, namely objective and subjective needs. Objective needs focus on student background information in the Nursing Study Program. Whereas the subjective needs focus on aspects of necessity, and Lacks

\section{The Result of Objective Needs Analysis}

Objective needs aim to determine the background of nursing students in learning Arabic. Data collection is done through an interview process through the presentation of questions that are answered 'yes' and 'no'. Researcher presents 15 questions: 1) Are you alumni of Madrasah Aliyah ?; 2) Are you pesantren alumni ?; 3) Does your family use Arabic ?; 4) Does your environment use Arabic ?; 5) Do you and your family use Arabic ?; 6) Have you ever studied Arabic outside the university ?; 7) Did you learn Arabic in high school or boarding school ?; 8) do you use Arabic vocabulary on social media or in daily communication ?; 9) do you often use Arabic vocabulary about nursing for daily communication ?; 10) do you often use Arabic in the university environment ?; 11) do you understand the need for Arabic to support work as a nurse ?; 12) do you master basic Arabic grammar ?; 13) Do you know the cultural context in Arabic? 14) do you often use Arabic both written and oral according to grammar rules ?; 15) do you know the use of formal and informal languages in Arabic? The following is a graph of the nursing students background.

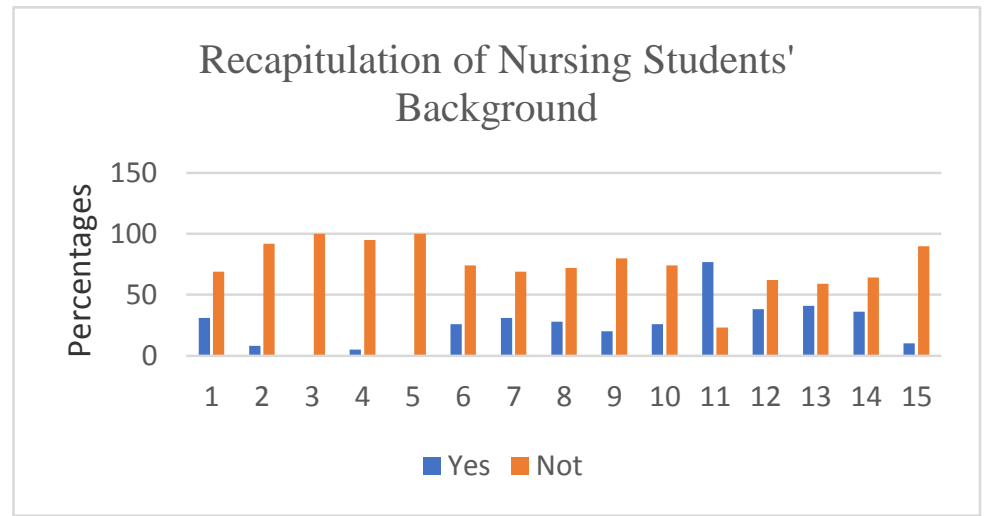

Graph. 1 Recapitulation of Nursing Students' Background

9 James Dean Brown, The elements of Language Curriculum: A Systematic Approach to Program Development, (Boston: Heinle \& Heinle Publishers, 1995).

10 Tom Hutchinson \& Alan Waters, English for Spesific Purposes, (Cambridge: Cambridge University Press, 1991), 59-61.

11 I.S.P. Nation \& John Macalister, Language Curriculum Design, (New York dan London: Routledge Taylor \& Francis Group, 2010), 24. 
The graph 1 concluded that most of the students did not come from Madrasab Aliyah graduates or Islamic boarding schools, such as the family environment. They do not use Arabic as a tool of communication everyday. Thus, both linguistic knowledge and Arabic learning experience are also low. So that, designing a syllabus for Arabic nursing learning must consider the order or level of difficulty. This is because the basic abilities of Arabic students are still low and differents.

\section{The Result of Subjective Needs Analysis}

1) Necessities Needs Analysis

Analysis of the necessity aspects addressed to leaders, course coordinators, and lecturers. The process of collecting data for needs analysis requires aspects of the interview. First is learning Arabic using syllabus. This means that learning Arabic nursing has been carried out in accordance with the syllabus set by the forgiving team of nursing Arabic subjects. Second, it is known that the syllabus for Arabic learning has been compiled by the Arabic language teaching team under the coordination of the general subject. This means that some lecturers have not been directly involved in compiling the syllabus. Although, they have not been fully involved in developing a syllabus that has determined learning outcomes. Third is the syllabus that has been determined in accordance with the results of the needs analysis, but the results of the document analysis show the syllabus still has shortcomings because it does not meet the objectives for learning Arabic specifically for nursing.

The fourth is the syllabus used is a communicative syllabus. This means that Arabic learning for nursing students is aimed at communicative abilities. The fifth is the existence of mandatory books and assignments that must be owned by students. During this time, the study program has required students to have a predetermined textbook. Seventh is a textbook designed also equipped with a manual for lecturers, so that it is easy to implement. Eighth is the Arabic learning method in the syllabus is discussion, lecture, practice, direct method, translation method and grammar. This type of teaching method is still considered saturating for students.

Ninth is the learning media is still not optimal in supporting the teaching and learning process. Tenth is a type of learning evaluation. Eleventh is the book used is still general, although some contents include the concept of health. Twelfth is the role of textbooks used for special purposes does not yet exist. This is consistent with the thirteenth question that Arabic textbooks specifically for nursing have not been designed or provided in accordance with the learning achievements to be achieved in the curriculum. The fourteenth question shows that this course is a compulsory subject. Fifteenth are questions related to the number of course credits as compulsory courses for nursing students. The sixteenth shows the number of lecturers who teach Arabic is 2 people. Seventeen shows teaching lecturers as permanent lecturers at the Nursing Academy with Arabic education background. 
Arabiyât Jurnal Pendidikan Bahasa Arab dan Kebahasaaraban, 7 (1), 2020

\section{2) Lacks Needs Analysis}

The following is a graphic presentation of lacks and wants needs analysis;

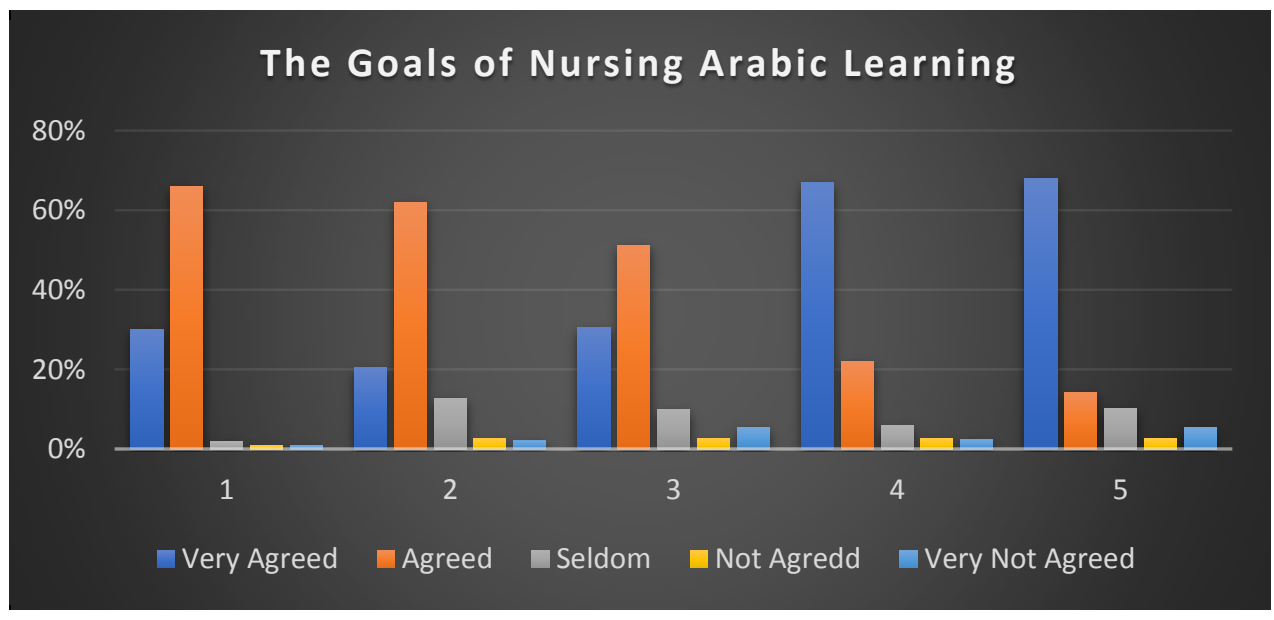

Graph 2. The Goals of Nursing Arabic Learning

Notes:

1: Mastering 4 Arabic language skills

2: Learning objectives include affective, cognitive, and psychomotor

3: Mastering Arabic learning resources

4: Types of tasks

5: Assessment of Arabic learning outcomes

Graph 2 shows the difficulties of students in achieving Arabic learning goals for nursing students. First, it is known that the mastery of four Arabic language skills is still difficult for students. This is in line with the syllabus orientation concept used when interviewing the needs analysis aspects of necessity. The purpose of the syllabus is focused on communicative. So that, it is difficult to achieve other Arabic skills. Thus, it has an impact on the mastery of knowledge, attitudes and skills. Especially, in the use of Arabic learning resources. Although some students have been able to use textbooks that are relevant to Arabic. While the ability of students in spelling written assignments is still low and difficulties in digesting the assessment process given by the lecturer. While the results of the analysis from the lecturer showed that of the 2 lecturers who taught this learninf thought the same as students. The level of achievement of learning goals that have been set is still low. Because there is a disjointed learning concept that has been set. This means that the goals set have not touched the essence of the needs of students as a whole and the industry. 
Ara6iyât Jurnal Pendidikan Bahasa Arab dan Kebahasaaraban, 7 (1), 2020

\section{Arabic Nursing Material}

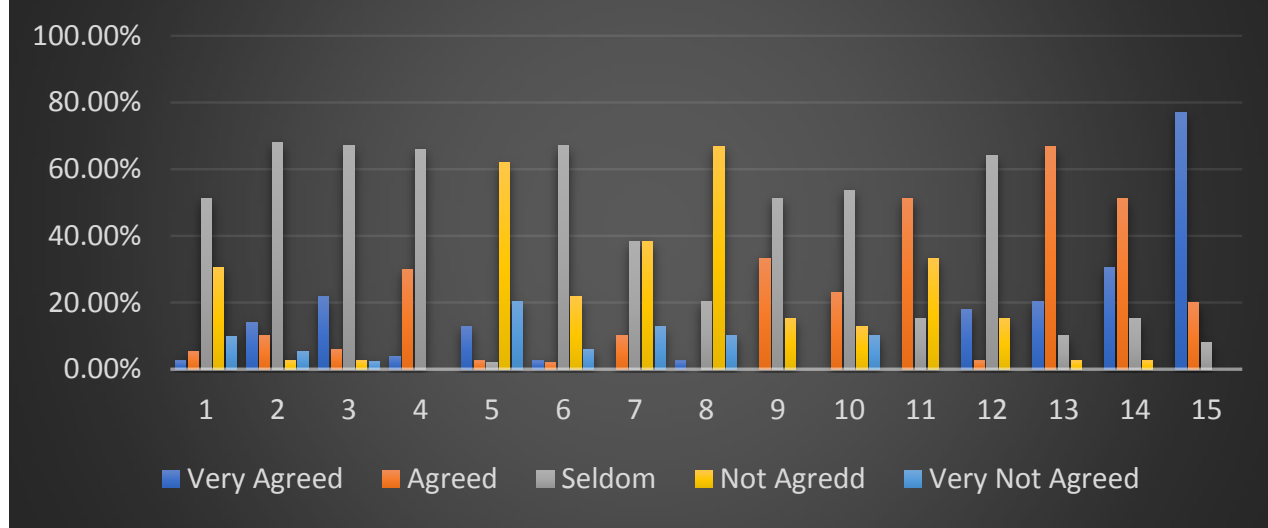

Graph 3. Arabic Nursing Material

Notes:

1: Learning themes

2: Hospital regulations

3: Daily communication

4: Nurse communication with the doctor

5: Emergency situation

6: Positive and negative work of nurses

7: Fill out a patient's health form or report

8: Patient examination procedures

9: Introduction of various drugs

10: Request and provide information

11: Enrichment of vocabulary in the health field in 4 Arabic skills

12: The use of technology in the health sector

13: Arabic vocabulary about nursing

14: Basic Arabic grammar patterns

15: Learning the intonation of the pronunciation of words in Arabic

Graph 3 conclude that students are still experiencing difficulties with the application of Arabic related to activities in the health sector. Themes that are still considered difficult to master are 1) learning themes related to nurses' tasks and activities; 2) hospital regulations; 3) daily communication; 4) nurse communication with doctors; 5) emergency situation; 6) positive and negative work of nurses; 7) filling out patient forms or health reports; 8) patient examination procedures; 9) introduction of various drugs; 10) request and provision of information; and 11) the use of technology in the health sector. While the material related to mastering the basics of Arabic grammar and vocabulary can still be learned easily. This opinion is in line with the view of the lecturer. 


\section{The Types of Activity inArabic Nursing Learning}

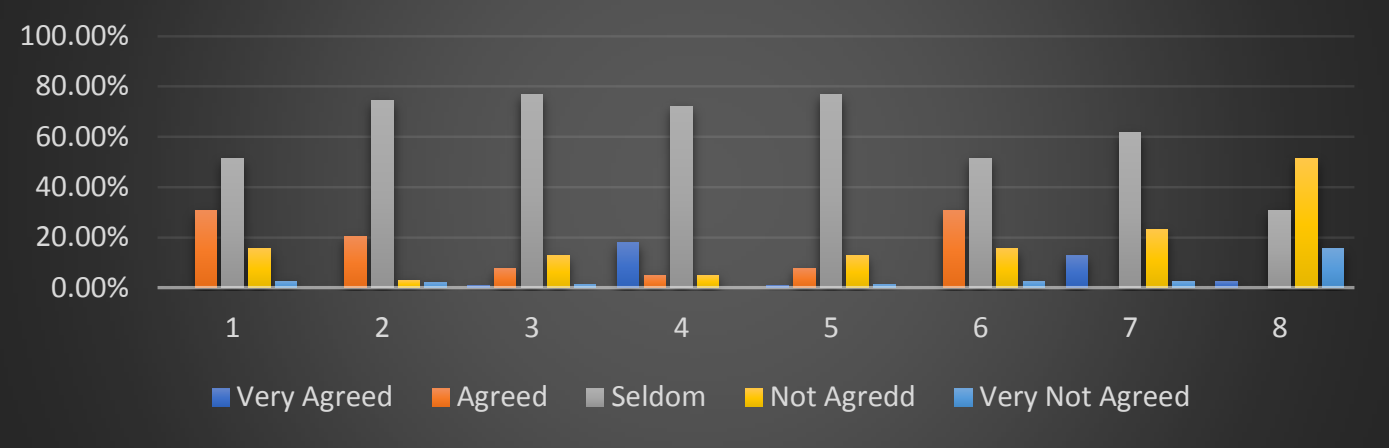

Graph 4. The Types of Activity in Arabic Nursing Learning

Notes:

1: The lecturer corrects the contents and errors of students' task

2: Speech

3: Your classmates comment on your work

4: The lecturer leads the discussion process

5: Discussion in groups

6: Discussion in pairs

7: Work on exercises in a book or worksheet

8: Provide student work review results

Learning activities in class are still considered difficult for students. This can be understood from the more dominant percentage level with doubtful answers. After the researcher analyzed the results of the interview, it was known that the cause was the context of learning Arabic for nursing in a different way. This of course must be adjusted to the vocabulary in the field of nursing. Therefore, the activities asked to students must be combined appropriately.

The first activity is the lecturer correcting the contents and errors of student task. This activity was felt difficult by students and lecturers. This means that the correction process carried out by lecturers is not optimal because of limited learning time, so that the results of student task must be corrected at home in part. Therefore, the process of correcting student practice must be regulated by class time. The second activity is speech. This activity does not provide the motivation to students because lecturers dominate the class and students only act passively during the learning process in class. This activity is difficult to provide an understanding of the learning context. The third activity is peer assessment, giving a fairly large percentage of results, namely $74 \%$. This activity is rarely done so the ability to evaluate student learning outcomes is still low. 
The fourth activity is the lecturer leading the discussion process. Students see it as an activity that does not provide opportunities for students to lead discussions in class. The fifth activity is discussion in groups which are still considered not going well. This activity is less than optimal because students often carry out their respective activities without building team collaboration in groups. The seventh activity is doing the exercises in the book provides less opportunity to develop creativity in the classroom. The last activity is giving the results of student work reviews. This activity is also still considered difficult because the ability of self-reflection of student learning outcomes is still low.

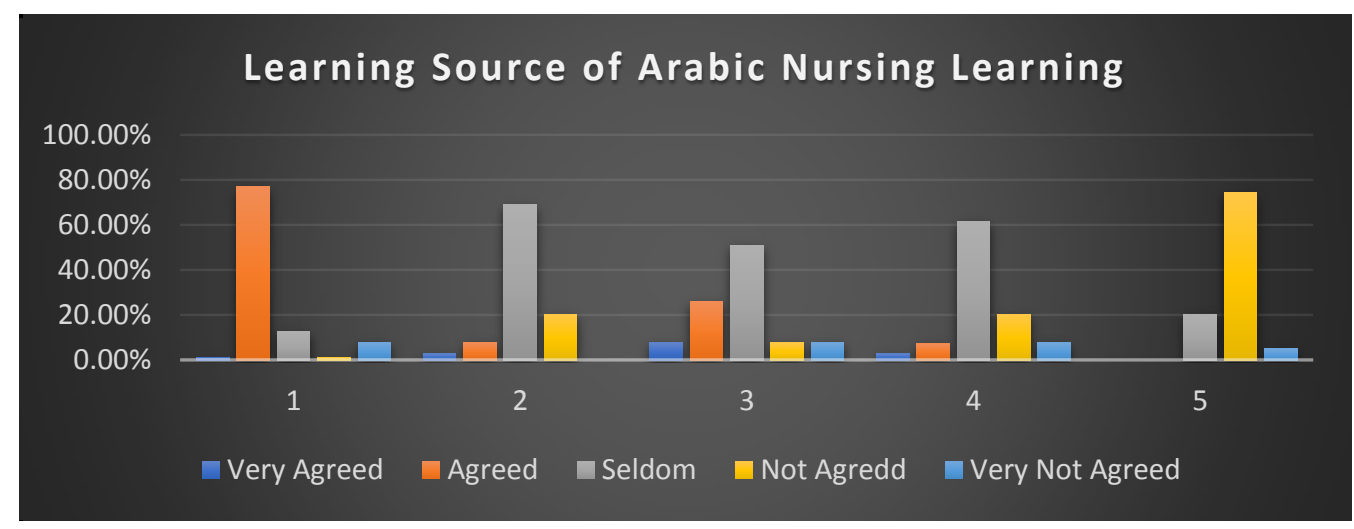

Graph 5. Learning Source of Arabic Nursing Learning

Notes:

$1 \quad:$ Textbook

$2 \quad$ : Dictionary

3 : Magazine

$4 \quad$ : Web based learning

$5 \quad$ : Journal

Graph 5 shows the level of difficulty of students in using learning resources. From the five data presented, textbooks are still very easy and indeed are often used in every learning process. Most learning resources that are rarely used are dictionaries, magazines, journals and material downloaded from the website. This is reinforced from the results of the needs analysis from lecturers who have stated that indeed students only use books as the main reference for learning. While other references are rarely used. Therefore, lecturers should provide motivation to students, so that they can utilize other learning resources. Because learning resources are not only taken from textbooks but also it is taken from other sources such as websites, magazines, dictionaries, mass media and so on. Thus, students will have broader knowledge and learning experience. 


\section{Types of Task in Nursing Arabic Learning}

$100.00 \%$

$80.00 \%$

$60.00 \%$

$40.00 \%$

$20.00 \%$

$0.00 \%$
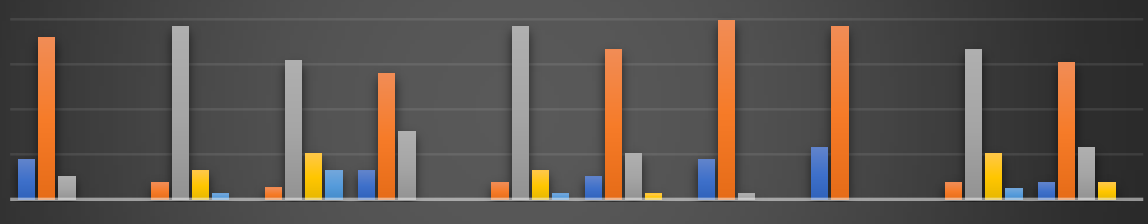

1

2

3

4

6

7

9

10

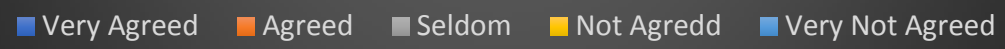

Graph 6. Types of Task in Nursing Arabic Learning

Notes:

1: Arabic basic grammar exercises

2: Finding vocabulary meaning Task

3: Filling in information from worksheets Task

4: Speaking exercises for giving and receiving health information

5: Making a report of the diagnosis

6: Reading the text related to health and look for the meaning of the contents of the text

7: Listening the video or audio related to health

8: Multiple choices task

9: Making a project about health

10: Oral Presentataion

Some types of assignments that are still considered difficult for students are exercises to find the meaning of vocabulary, exercises to fill in information from worksheets, make reports on the results of diagnoses, make projects about health. Thus, the concept of the type of task must be adjusted back to the abilities that students have. This is in line with the opinions of lecturers who stated that many students had difficulty in completing assignments. Therefore, lecturers must modify the types of assignments with learning media or other assignments. This is done to avoid boredom during the learning process in class. Moreover, the global era has demanded that lecturers become someone who is creative and innovative in carrying out the teaching and learning process.

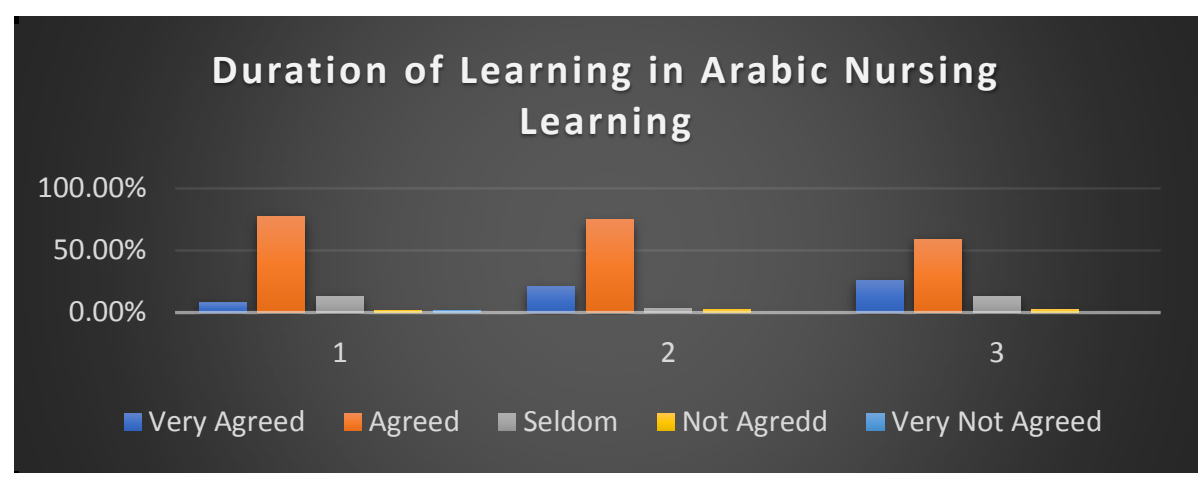

Graph. 7 Duration Learning in Arabic Nursing Learning 
Notes:

$1: 100$ minutes/once in a week

$2: 150$ minutes/once in a week

$3: 200$ minutes/twice in a week

Duration of learning which has been set does not give much difficulty to students while studying Arabic in class. Arabic learning that must be taken by students are set at 2 credits or 100 minutes. So that, the lecturer must arrange the time of learning activities in class appropriately.

\section{Discussion}

Based on data analysis show that learning of Arabic for Nursing Study Programs is more qualified begins with the preparation of an appropriate syllabus for learning Arabic. Because the syllabus contains complete learning activities related to all material that must be mastered by students. $\mathrm{Ur}^{12}$ argues that the syllabus is a document which contains specifically a series of lists or entries. The list is all the things taught in the learning process where the syllabus has been made. The actual components of the list include content (words, structure, topics) or processes (exercises, methods). Thus, another factor that supports learning Arabic is the use of appropriate methods. Because language is a culture that must be learned through practice. The selection of the task-based syllabus model is considered the right model, so that learning Arabic is more enjoyable.

In the Republic of Indonesia's Presidential Regulation No. 8/2012, it is said that the Indonesian National Qualifications, hereinafter abbreviated as KKNI (Kerangka Kualifikasi Nasional Indonesia), constitute a competency qualification gap framework that can juxtapose, equalize, and integrate between the education and work training fields as well as work experience in the context of providing recognition of work competence in accordance with the structure jobs in various sectors. From the elaboration, the task-based model of syllabus on Arabic nursing assignments leads to the learning output to be achieved, which is to produce nursing students who have foreign language skills, namely Arabic as a supporting ability to their skills in the nursing field. Previous research has been done to determine the attachment between the task and learning. As Mohamed did, entitled Task-based incidental vocabulary learning in L2 Arabic: The role of proficiency and task performance. The results of the study illustrate that there are valid hypotheses among various factors that influence the acquisition of vocabulary. This study provides recommendations that pedagogic practices can accommodate foreign language learning. ${ }^{13}$

Press, 2009).

12 P. Ur., A Course in Language Teaching Practice and Theory, (Cambridge: Cambridge University

13 A. A. Mohamed, "Task-based incidental vocabulary learning in L2 Arabic: The role of proficiency and task performance", Journal of the National Council of Less Commonly Taught Languages, 17 (Spring), 2015. 
The syllabus is designed to provide solutions to the completion of learning related to practical needs. ${ }^{14}$ From this research, it was found that the task-based syllabus is related to the content of language learning and the use of task variations to train students' language use. Whereas task-based learning creates language learning conditions that focus on using the ability to do tasks or activities, it is not on teaching grammar. So, the task-based syllabus is closely related how to create varied teaching and learning in learning activities. The same has been done by Mahmoudi, Yasin, \& Amirkhiz who compared task-based and structured syllabus for listening learning. ${ }^{15}$

The implication of the research is aimed at the nursing study program that the analysis of needs analysis for a task-based Arabic syllabus model can be used as a reference or guide in mapping the curriculum or Arabic learning needs in the Arabic study program. So far Arabic is only given 2 credits and learning Arabic is general. The material provided is really Arabic language material and does not focus toward vocabulary or nursing content. Thus, this syllabus model can be taken into consideration whether learning Arabic is really intended specifically for nursing science or study programs to add to the learning credits.

\section{Conclusion}

The syllabus currently used is not in accordance with learning outcomes which expected in the Higher Education National Standards. Curriculum aims to build equality in the quality of Indonesian human resources with foreign human resources in various sectors. Indonesia has set qualifications at 9 levels. This level is arranged starting from junior high school level to tertiary level 3. In addition, the nine levels also clearly describe a career in the world of work, the level of experience or independence of one's learning and professional level at work. The finding concluded that students and lecturers wanted an Arabic nursing syllabus was appropriate to the needs of the study program and met global challenges.[]

\section{REFERENCES}

Ary, Donald., Lucy Cheser Jacobs, Christine K. Sorensen Irvine, \& David A. Walker. Introducation to Research in Education, Boston: Cengage, 2009.

Brown, James Dean. The elements of Language Curriculum: A Systematic Approach to Program Development. Boston: Heinle \& Heinle Publishers, 1995.

Bazyar, Z., M. Dastpak, \& A. Taghinezhad. "Syllabus Design and Needs Analysis of Students in Educational System", Australian International Academic Centre, Vol. 6, No. 4, 2015.

14 A. Salimi, S. Dadashpopur, A. Shafaei, \& H. Asadollahf, "Critical Review of Approaches to Foreign Language Syllabus Design: Task-Based Syllabus (A Shortcut)", Procedia - Social and Behavioral Sciences, 46, 2012, 828-832.

${ }^{15}$ L. Mahmoudi, S. Yasin, \& Y. Amirkhiz, "Structure-based vs. Task-based Syllabus: The Effect of Type of Syllabus on Listening Comprehension Ability of Iranian University Students", Theory and Practice in Language Studies, Vol. 1, No. 10, 2011, 1388-1393. 
Ara6iyât Jurnal Pendidikan Bahasa Arab dan Kebahasaaraban, 7 (1), 2020

Cowling, J. D. "Needs analysis: Planning a syllabus for a series of intensive workplace courses at a leading Japanese company", English for Specific Purposes, Vol. 26, No. 4, 2007.

al-Hamlan, S. \& A. A. Baniabdelrahman. "A Needs Analysis Approach to EFL Syllabus Development for Second Grade Students in Secondary Education in Saudi Arabia: A Descriptive Analytical Approach to Students' Needs", American International Journal of Contemporary Research, Vol. 5, No. 1, 2015.

Hutchinson, Tom., \& Alan Waters. English for Spesific Purposes. Cambridge: Cambridge University Press, 1991.

Jones, N. N. "Human Centered Syllabus Design: Positioning Our Students As Expert End-Users", Computers and Composition, 49, 2018.

Mohamed, A.A. "Task-based incidental vocabulary learning in L2 Arabic: The role of proficiency and task performance", Journal of the National Council of Less Commonly Taught Languages, 17 (Spring), 2015.

Mahmoudi, L., S. Yasin, \& Y. Amirkhiz. "Structure-based vs. Task-based Syllabus: The Effect of Type of Syllabus on Listening Comprehension Ability of Iranian University Students", Theory and Practice in Language Studies, Vol. 1, No. 10, 2011.

Nation, I.S.P. \& John Macalister. Language Curriculum Design. New York \& London: Routledge Taylor \& Francis Group, 2010.

Rahimpour, M. "Current trends on syllabus design in foreign language instruction", Procedia - Social and Behavioral Sciences, Vol. 2, No. 2, 2010 a.

Saleh, A. A. \& T. Elyas. "Advances in language and literary studies : AL \&amp; LS", Advances in Language and Literary Studies, Vol. 6, 2015.

Salimi, A., S. Dadashpopur, A. Shafaei, \& H. Asadollahf. "Critical Review of Approaches to Foreign Language Syllabus Design: Task-Based Syllabus (A Shortcut)", Procedia - Social and Behavioral Sciences, 46, 2012.

Ur, P. A Course in Language Teaching Practice and Theory. Cambridge: Cambridge University Press, 2009.

Woods, A., A. Luke, \& K. Weir. "Curriculum and Syllabus Design", International Encyclopedia of Education, 2010. 